\title{
STRATEGIC MANAGEMENT ACCOUNTING IN THE MANAGEMENT OF LOGISTICS PROCESSES. RESULTS OF THE PILOT STUDIES
}

\begin{abstract}
Process management in enterprises, including the management of logistic processes is of interest to both science and business practice. It requires information support to provide quantitative, valuable and qualitative information. Management accounting may be such a subsystem of information in a company. In the publication, the considerations were narrowed down to strategic management accounting. The aim of the study is: (1) to identify the role of strategic management accounting in the management of logistics processes; (2) to pre-define the need and direction for in-depth scientific research in the field of strategic management accounting in the implementation of logistics processes. The following hypothesis has been adopted: strategic management accounting generates a wide range of information on logistics processes, but in practice these opportunities are not used by managers and business owners. The hypothesis was positively verified within the framework of the research conducted with the use of literature analysis, results of the research project NN 113005839 carried out in 2010-2013, the author's own experience and pilot studies (direct interviews) in 10 enterprises.
\end{abstract}

Keywords: accounting, strategic management accounting, logistics processes.

\section{INTRODUCTION}

Accounting is commonly characterized as an information system, international business language, system of measurement, valuation and presentation of economic events occurring in the company. The evolution of accounting over the last 100 years has shown its division into financial and management accounting. As a result of increased international competition and the need for information support practices in the area of operational and strategic management, management accounting was divided internally into strategic and operational accounting. In the literature, as well as in business practice, more and more attention is paid to strategic management as a key approach, focused on the long-term existence of the company. And one approach to this is process management, which can be based on logistical processes.

Logistics processes permeate all events occurring in companies. Moreover, they focus key activities from the point of view of creating value for the customer as well as for the company itself. It is therefore important that decisions on the management of logistics

\footnotetext{
${ }^{1}$ Piotr Szczypa, DSc, PhD, Associate Prof., Chair of Finance, Accounting and Logistics, Faculty of Social and Technical Sciences, State Higher Vocational School in Konin. Dr hab. Piotr Szczypa, prof. nadzw., Katedra Finansów, Rachunkowości i Logistyki, Wydział Nauk Społecznych i Technicznych, PWSZ w Koninie.
} 
processes are supported by reliable and timely information of a quantitative, valuable and qualitative nature. Management accounting is the system that can provide this information. Due to the limited size of the article, attention will be paid to strategic management accounting. On the other hand, considerations and research results devoted to operational management accounting in the management of logistic processes are the subject of a separate study.

\section{OBJECTIVE AND METHODOLOGY ADOPTED}

In this article, two goals have been adopted for implementation. The first theoretical one, which is to identify the role of strategic management accounting in the management of logistics processes. The second, relating to business practice, is an initial identification of the need and direction for in-depth scientific research in the field of strategic management accounting in the implementation of logistics processes. The article assumes the following hypothesis: strategic management accounting generates a wide range of information on logistics processes, but in practice these opportunities are not used by managers and business owners. On the basis of the above assumptions, it can be concluded that the object of the research is the subsystem of strategic management accounting and logistic processes, and the subject the enterprises.

In order to achieve the assumed goals and verify the hypothesis, the following research methods were used: (1) literature analysis; (2) direct interview; (3) deduction and induction. The author used his own experience as an assessor of logistics processes in companies and implementation of accounting tools, as well as the results of a research project financed from budgetary funds for science in the years 2010-2013 as a research project NN 113005839 under the name of Using accounting tools in logistics - contemporary experience of Poland, Germany and Belarus, of which he was a member. One of the objectives of the project was to analyze and evaluate the existing accounting system solutions for the needs of decision making processes in the logistics of enterprises on the basis of the experiences of Poland, Germany and Belarus and to design an accounting model supporting decision making processes in the logistics of enterprises. In addition, in the first quarter of 2018, pilot studies were conducted on a group of 10 companies from the Zachodniopomorskie and Wielkopolskie Voivodeships, keeping accounting books and declaring the use of management accounting tools. These surveys, which were carried out in the form of a face-to-face interview with the chief accountants, were designed to confirm the desirability of conducting in-depth research into the role of management accounting in the management of logistics processes.

\section{CHARACTERIZATION OF KEY TERMS}

A. Halachmi points out that if something cannot be measured, it cannot be understood, it cannot be managed, and consequently it cannot be optimized ${ }^{2}$. A specific measurement and valuation system in this respect should be recognized in management accounting. As G. Lew rightly points out, "Management accounting, like many other areas of modern

\footnotetext{
2 A. Halachmi, Performance Measurement is Only one Way of Managing performance, "International Journal of Productivity and Performance Management" 2005, Vol. 54, issue 7, p. 503-504.
} 
Table 1. Interpretation of key concepts

\begin{tabular}{|c|c|c|}
\hline Object of interest & Definition & Further information \\
\hline $\begin{array}{l}\text { Strategic } \\
\text { management } \\
\text { accounting }\end{array}$ & $\begin{array}{l}\text { Information system focused on } \\
\text { measurement and valuation } \\
\text { through acquisition, processing } \\
\text { and presentation of financial and } \\
\text { non-financial information on } \\
\text { past and present economic } \\
\text { phenomena, aimed at supporting } \\
\text { strategic management, } \\
\text { especially in the framework of } \\
\text { long-term planning using } \\
\text { specific methods. }\end{array}$ & $\begin{array}{l}\text { Information from management } \\
\text { accounting should be relevant and } \\
\text { useful, i.e. the benefits of such } \\
\text { information should outweigh the costs } \\
\text { of obtaining it. Management accounting } \\
\text { is a flexible information system that can } \\
\text { fill the gaps in financial accounting, } \\
\text { especially for measuring and measuring } \\
\text { economic phenomena of a very complex } \\
\text { nature, with elements of qualitative and } \\
\text { intangible, or even emotional, } \\
\text { assessment. }\end{array}$ \\
\hline Logistical processes & $\begin{array}{l}\text { A structured set of interrelated } \\
\text { logistical activities and } \\
\text { activities. }\end{array}$ & $\begin{array}{l}\text { Logistical processes cover both physical } \\
\text { and information flows. }\end{array}$ \\
\hline $\begin{array}{l}\text { Management of } \\
\text { logistical processes }\end{array}$ & $\begin{array}{l}\text { All activities related to planning, } \\
\text { organizing, motivating and } \\
\text { controlling resources and their } \\
\text { measures within logistic } \\
\text { processes. }\end{array}$ & $\begin{array}{l}\text { The management of logistics processes } \\
\text { is primarily focused on: } \\
\text { - resources involved in the } \\
\text { implementation of processes (human, } \\
\text { material, financial, information } \\
\text { resources); } \\
\text { - the economic categories } \\
\text { characterizing the resources involved } \\
\text { (e.g. costs, expenses, quality). }\end{array}$ \\
\hline $\begin{array}{l}\text { Strategic } \\
\text { management } \\
\text { accounting in the } \\
\text { management of } \\
\text { logistic processes }\end{array}$ & $\begin{array}{l}\text { Information system focused on } \\
\text { measurement and valuation } \\
\text { through acquisition, processing } \\
\text { and presentation of financial and } \\
\text { non-financial information } \\
\text { supporting strategic (long-term) } \\
\text { decision-making within the } \\
\text { framework of planning, } \\
\text { organizing, motivating and } \\
\text { controlling activities and } \\
\text { activities forming logistic } \\
\text { processes. }\end{array}$ & $\begin{array}{l}\text { The role of strategic management } \\
\text { accounting in the management of } \\
\text { logistics processes is manifested } \\
\text { primarily in information support for the } \\
\text { managerial staff in the process of } \\
\text { making strategic decisions relating to } \\
\text { several years of future periods. }\end{array}$ \\
\hline
\end{tabular}

Source: own.

economic science, is constantly changing. The dynamics of these changes is gaining momentum with the progressing globalization processes in the world economy. Changes in management accounting took place in three basic aspects: accounting theory, canon of knowledge from management accounting and methods of management accounting" 3 . With this in mind, a preliminary attempt could be made to assess the possibility of using

${ }^{3}$ G. Lew, Rachunek kosztów klienta w zarządzaniu przedsiębiorstwem handlowym, Rzeszów 2015, p. 281. 
management accounting, in the case of this article strategic management accounting for the management of logistical processes. However, first of all, in order to clearly and correctly interpret the analyzed issue, it is necessary to define key terms (Table 1), such as:

- strategic management accounting;

- logistics processes;

- management of logistics processes;

- strategic management accounting in the management of logistics processes.

\section{RELATION: STRATEGIC MANAGEMENT ACCOUNTING - MANAGEMENT OF LOGISTICS PROCESSES}

D. Tokarska rightly points out that: "Management accounting supports the management of a company in its various areas. Although management accounting is generally associated mainly with the operating costs of a company, it also has a significant impact on employee motivation and human resources decisions through optimization and control functions. An employee who is not motivated or who is not motivated properly poses a threat to the

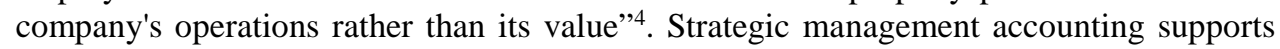
strategic management and should be identified not only with costs but also with future revenues and even non-financial measures, such as employee and customer satisfaction.

The literature indicates that activities and activities constituting logistic processes may be considered in three decision-making areas: operational, tactical and strategic ${ }^{5}$. Strategic decisions are the main subject of considerations in this report. The management of logistic processes is a decision-making process, which concerns the creation of a specific concept of logistic activities carried out in the logistics system of the company. Logistics management is not a separate concept of management, and thus it does not use management instruments specific to it only ${ }^{6}$. Therefore, within the framework of logistics management instruments it is possible to identify management accounting, within the framework of longterm (strategic) decisions - strategic management accounting.

The relationship between strategic management accounting and the management of logistic processes should be seen primarily as part of the main accounting function, i.e. information support. Information itself is widely recognized as a key productive factor for social and economic development. "Having good and useful information before others who are also interested in it helps to avoid faulty or too risky decisions and enables anticipatory actions to be taken by others, taking advantage of the economic situation and emerging opportunities to gain a high market position"7. Effective information management in a company requires managers to observe the following principles 8 :

- Enterprises should receive selected information that is necessary for the decisionmaking process;

${ }^{4}$ D. Tokarska, Narzędzia rachunkowości zarządczej jako wsparcie systemów motywacyjnych [w:] Studia Ekonomiczne Zeszyty Naukowe UE w Katowicach 300, Katowice 2016, p. 184.

5 I. Dembińska-Cyran, Zarządzanie procesami logistycznymi w przedsiębiorstwach ustugowych [w:] Przedsiębiorstwo ustugowe. Zarzadzanie, red. B. Filipiak, A. Panasiuk, Warszawa 2008, p. 284.

${ }^{6}$ Ibidem, p. 293.

7 J. Buko, G. Wolska, Zarzadzanie procesami logistycznymi w przedsiębiorstwach ustugowych [w:] Przedsiębiorstwo ustugowe..., p. 253.

${ }^{8}$ Cz. Sobków, Podstawy zarządzania, Włocławek 2003, p. 85-87. 
- Creating and sending insignificant information entails unnecessary costs;

- malfunctioning information systems are the cause of low business flexibility.

In view of the above, it is concluded that the management accounting system and its strategic part, the management accounting, is an information system which will ensure compliance with these principles.

\section{THE ROLE OF STRATEGIC MANAGEMENT ACCOUNTING IN THE MANAGEMENT OF LOGISTICS PROCESSES IN THE CONTEXT OF PILOT STUDIES}

The implementation of logistic processes should manifest itself in the pursuit?:

- better use of resources;

- improving the efficiency of logistics flows;

- the elimination of unnecessary or inefficient processes;

- shortening the duration of processes;

- the efficiency of the information system

- high quality of service;

- high flexibility to meet customer needs;

- reduction of costs by minimizing the costs of logistics processes.

As part of logistics process management, various instruments are used for rational decision-making by managers, e.g.: stock and transport control methods, mapping of logistics processes, decision point analysis, critical path analysis, $\mathrm{ABC}$ analysis, Pareto analysis, etc. These instruments and other solutions used by the managerial staff to plan, organize, motivate and control events within the logistic processes require various information. Strategic management accounting can provide it. The research project carried out in 2010-2013 assumes that not all types of logistic processes will be subject to strategic management accounting. Strategic management accounting should informally support the following logistic processes: supply process, distribution process, transport process, storage process, inventory management process. Other logistic processes, namely: handling process, order processing process, packaging process, identification automation process, due to the specificity of logistic activities taking place in them do not meet the conditions to become the subject of interest of strategic management accounting.

From the general information function of strategic management accounting, specific functions can be distinguished, namely: planning, optimization, motivation and control functions. Tables 2, 3 and 4 below will describe the role of strategic management accounting in the management of these logistical processes, broken down by its specific functions. In addition, each title of information will be accompanied by the result of the pilot studies carried out, which will indicate whether the information is (Yes) or is not (No) to be obtained from the management accounts of the enterprises concerned. The "Yes" option was already indicated in the case of a given situation in the three surveyed companies. Table 2 presents the planning and optimization function of strategic management accounting in the implementation of selected logistics processes in the context of the results of pilot studies.

${ }^{9}$ I. Dembińska-Cyran, Zarządzanie procesami logistycznymi..., p. 295. 
Table 2. Planning and optimization function of strategic management accounting in the implementation of logistical processes in the context of the results of the pilot studies

\begin{tabular}{|c|c|c|c|}
\hline \multirow[t]{2}{*}{$\begin{array}{l}\text { Logistical } \\
\text { processes }\end{array}$} & \multirow[t]{2}{*}{$\begin{array}{l}\text { The role of strategic management accounting is expressed by } \\
\text { the provision of ex ante information concerning }\end{array}$} & \multicolumn{2}{|c|}{$\begin{array}{c}\text { Use of } \\
\text { management } \\
\text { accounting to } \\
\text { retrieve the } \\
\text { information } \\
\end{array}$} \\
\hline & & Yes & No \\
\hline \multirow{4}{*}{$\begin{array}{l}\text { The sourcing } \\
\text { process }\end{array}$} & $\begin{array}{l}\text { decision costs related to the selection of potential suppliers of } \\
\text { materials, semi-finished products, goods }\end{array}$ & $\mathrm{X}$ & \\
\hline & the quality of the services provided by future suppliers & & $\mathrm{X}$ \\
\hline & the costs of ordering from suppliers & & $\mathrm{X}$ \\
\hline & make or buy/outsource costs & & $\mathrm{X}$ \\
\hline \multirow{8}{*}{$\begin{array}{l}\text { The } \\
\text { distribution } \\
\text { process }\end{array}$} & the costs of selection of the distribution channel & & $X$ \\
\hline & costs of processing customer orders & & $X$ \\
\hline & packing costs & $\mathrm{X}$ & \\
\hline & the costs of transporting and storing stocks & $\mathrm{X}$ & \\
\hline & the costs of quantitative and qualitative inventory control & & $\mathrm{X}$ \\
\hline & $\begin{array}{l}\text { decision costs related to the choice of stock structure in the supply } \\
\text { chain }\end{array}$ & & $\mathrm{X}$ \\
\hline & $\begin{array}{l}\text { the decision-making costs of selecting the location of the } \\
\text { distribution center }\end{array}$ & $\mathrm{X}$ & \\
\hline & reimbursement handling costs & & $\mathrm{X}$ \\
\hline \multirow{5}{*}{$\begin{array}{l}\text { Transportation } \\
\text { process }\end{array}$} & transport costs, broken down by mode & & $\mathrm{X}$ \\
\hline & the operating costs of the various modes of transport & & $\mathrm{X}$ \\
\hline & $\begin{array}{l}\text { the wage and salary-related costs of drivers in the various } \\
\text { employment and salary options }\end{array}$ & & $\mathrm{X}$ \\
\hline & transport costs per accepted object & & $\mathrm{X}$ \\
\hline & $\begin{array}{l}\text { the cost of selection decisions, whether in-house or outbound } \\
\text { transport }\end{array}$ & $\mathrm{X}$ & \\
\hline \multirow{6}{*}{$\begin{array}{l}\text { Storage } \\
\text { process }\end{array}$} & decision costs related to selection: own or third-party warehouse & $\mathrm{X}$ & \\
\hline & decision costs related to the choice of warehouse location & & $\mathrm{X}$ \\
\hline & the quality of storage services & & $\mathrm{X}$ \\
\hline & storage costs attributable to the assumed cost item & & $\mathrm{X}$ \\
\hline & $\begin{array}{l}\text { the wage and salary-related costs in the various employment and } \\
\text { remuneration variants }\end{array}$ & & $\mathrm{X}$ \\
\hline & the cost of storage facilities & $\mathrm{X}$ & \\
\hline \multirow{5}{*}{$\begin{array}{l}\text { Inventory } \\
\text { management } \\
\text { process }\end{array}$} & $\begin{array}{l}\text { costs of inventory management, broken down by different amounts } \\
\text { of materials, semi-finished products, goods maintenance }\end{array}$ & & $\mathrm{X}$ \\
\hline & $\begin{array}{l}\text { costs of inventory management, depending on the adopted variant } \\
\text { of the structure of particular items of inventory }\end{array}$ & & $\mathrm{X}$ \\
\hline & $\begin{array}{l}\text { costs of inventory management depending on the share in value and } \\
\text { quantity (ABC analysis) }\end{array}$ & & $X$ \\
\hline & $\begin{array}{l}\text { changes in the costs of inventory management in relation to the } \\
\text { demand for and supply of ordered materials and semi-finished } \\
\text { products }\end{array}$ & & $\mathrm{X}$ \\
\hline & $\begin{array}{l}\text { changes in the costs of inventory management, depending on the } \\
\text { demand and supply for the offered products and goods }\end{array}$ & & $\mathrm{X}$ \\
\hline
\end{tabular}

Source: Own calculations based on the results of pilot studies and P. Szczypa, Rola strategicznej rachunkowości zarządczej w zarządzaniu procesami logistycznymi [w:] Wykorzystanie narzędzi rachunkowości w logistyce. Doświadczenia przedsiębiorstw polskich, niemieckich i białoruskich, red. B. Filipiak, Warszawa 2013, p. 63. 
From the contents of Table 2 it can be concluded that the role of strategic management accounting in the planning function is expressed by providing forward-looking, long-term financial and non-financial information supporting strategic management of logistic processes, especially concerning logistic costs and expenses and the quality of logistic processes, which are of key importance for the achievement of company objectives, including gaining long-term competitive advantage, inter alia by creating the basis for selecting optimal variants for the implementation of logistic processes. The results of the pilot studies indicate that the use of strategic management accounting is limited to the acquisition of the information indicated in Table 2. According to the results, management accounting supports information from 1 to 2 only for given logistic processes, referring to basic decision-making processes in the field of long-term management of logistic processes.

Table 3. Incentive function of strategic management accounting in the implementation of logistics processes in the context of the results of pilot studies

\begin{tabular}{|c|c|c|c|}
\hline \multirow[t]{2}{*}{$\begin{array}{l}\text { Logistical } \\
\text { processes }\end{array}$} & \multirow[t]{2}{*}{$\begin{array}{l}\text { The role of strategic management accounting is expressed } \\
\text { by the provision of ex ante and ex post information on }\end{array}$} & \multicolumn{2}{|c|}{$\begin{array}{l}\text { Use of } \\
\text { management } \\
\text { accounting to } \\
\text { retrieve the } \\
\text { information }\end{array}$} \\
\hline & & Yes & No \\
\hline \multirow{2}{*}{$\begin{array}{l}\text { The sourcing } \\
\text { process }\end{array}$} & $\begin{array}{l}\text { controlled costs related to the selection of potential suppliers of } \\
\text { materials, semi-finished products, goods }\end{array}$ & & $\mathrm{X}$ \\
\hline & $\begin{array}{l}\text { Point quality assessment of individual suppliers in accordance } \\
\text { with the adopted evaluation scale. }\end{array}$ & $\mathrm{X}$ & \\
\hline \multirow{4}{*}{$\begin{array}{l}\text { The distribution } \\
\text { process }\end{array}$} & the controlled costs of selecting a distribution channel & & $\mathrm{X}$ \\
\hline & $\begin{array}{l}\text { the controlled costs of selecting the location of the distribution } \\
\text { center }\end{array}$ & & $\mathrm{X}$ \\
\hline & $\begin{array}{l}\text { the costs of controlled selection of the stock structure in the } \\
\text { supply chain }\end{array}$ & & $\mathrm{X}$ \\
\hline & $\begin{array}{l}\text { Point assessment of the quality of return handling in accordance } \\
\text { with the adopted evaluation scale. }\end{array}$ & & $\mathrm{X}$ \\
\hline \multirow{3}{*}{$\begin{array}{l}\text { Transportation } \\
\text { process }\end{array}$} & the controlled costs of selecting the means of transport & & $\mathrm{X}$ \\
\hline & $\begin{array}{l}\text { a point-based assessment of the quality of individual carriers in } \\
\text { accordance with the established assessment scale }\end{array}$ & $\mathrm{X}$ & \\
\hline & $\begin{array}{l}\text { controlled costs related to the employment system and } \\
\text { remuneration of employees }\end{array}$ & & $\mathrm{X}$ \\
\hline \multirow{3}{*}{ Storage process } & the controlled costs of selecting the place of storage & & $\mathrm{X}$ \\
\hline & $\begin{array}{l}\text { the controlled costs associated with the choice of the form of } \\
\text { ownership of the warehouse }\end{array}$ & & $\mathrm{X}$ \\
\hline & $\begin{array}{l}\text { a point-based assessment of the quality of storage according to an } \\
\text { agreed scale }\end{array}$ & & $\mathrm{X}$ \\
\hline \multirow{2}{*}{$\begin{array}{l}\text { Inventory } \\
\text { management } \\
\text { process }\end{array}$} & $\begin{array}{l}\text { costs of controlled management of stocks of materials and semi- } \\
\text { finished products }\end{array}$ & & $X$ \\
\hline & $\begin{array}{l}\text { the costs of controlled management of stocks of products and } \\
\text { goods }\end{array}$ & & $\mathrm{X}$ \\
\hline
\end{tabular}

Source: Own calculations based on the results of pilot studies and P. Szczypa, Rola strategicznej rachunkowości zarządczej w zarządzaniu procesami logistycznymi [w:] Wykorzystanie narzędzi..., p. 64. 
The role of strategic management accounting in the incentive function (tables 3 ) is expressed by the provision of financial and non-financial information enabling the creation of measures and evaluation criteria, as well as a system of incentives for employees responsible for the results (costs, quality) of the implementation of logistic processes in the long term. The results of the pilot studies show that strategic management accounting in the companies analyzed is applicable to the qualitative assessment of suppliers and haulers.

Table 4. Control function of strategic management accounting in the implementation of logistical processes in the context of the results of the pilot studies

\begin{tabular}{|c|c|c|c|}
\hline \multirow[t]{2}{*}{$\begin{array}{l}\text { Logistical } \\
\text { processes }\end{array}$} & \multirow[t]{2}{*}{$\begin{array}{l}\text { The role of strategic management accounting is expressed by } \\
\text { the provision of ex post information concerning }\end{array}$} & \multicolumn{2}{|c|}{$\begin{array}{c}\text { Use of } \\
\text { management } \\
\text { accounting to } \\
\text { retrieve the } \\
\text { information }\end{array}$} \\
\hline & & Yes & No \\
\hline $\begin{array}{l}\text { The sourcing } \\
\text { process }\end{array}$ & $\begin{array}{l}\text { the costs of loss of profit incurred in connection with the selection } \\
\text { of the supplier }\end{array}$ & & $\mathrm{X}$ \\
\hline \multirow{3}{*}{$\begin{array}{l}\text { The } \\
\text { distribution } \\
\text { process }\end{array}$} & the cost of lost profit in selecting the distribution channel & & $\mathrm{X}$ \\
\hline & $\begin{array}{l}\text { the cost of lost benefits resulting from the choice of inventory } \\
\text { structure in the supply chain }\end{array}$ & & $\mathrm{X}$ \\
\hline & $\begin{array}{l}\text { the costs of lost benefits resulting from the choice of location of the } \\
\text { distribution center }\end{array}$ & & $\mathrm{X}$ \\
\hline \multirow{3}{*}{$\begin{array}{l}\text { Transportation } \\
\text { process }\end{array}$} & $\begin{array}{l}\text { the costs of lost benefits resulting from the choice of means of } \\
\text { transport }\end{array}$ & & $\mathrm{X}$ \\
\hline & $\begin{array}{l}\text { the costs of lost benefits resulting from the choice of the system of } \\
\text { hiring and remunerating drivers }\end{array}$ & & $\mathrm{X}$ \\
\hline & $\begin{array}{l}\text { costs of lost benefits resulting from the choice of own or third party } \\
\text { transport }\end{array}$ & & $\mathrm{X}$ \\
\hline \multirow{2}{*}{$\begin{array}{l}\text { Storage } \\
\text { process }\end{array}$} & $\begin{array}{l}\text { the costs of lost benefits resulting from the choice of storage } \\
\text { location }\end{array}$ & & $\mathrm{X}$ \\
\hline & $\begin{array}{l}\text { costs of lost profits resulting from the choice of own or third party } \\
\text { warehouse }\end{array}$ & & $\mathrm{X}$ \\
\hline \multirow{2}{*}{$\begin{array}{l}\text { Inventory } \\
\text { management } \\
\text { process }\end{array}$} & $\begin{array}{l}\text { the costs of lost benefits in relation to the chosen demand and } \\
\text { supply option for the procured materials and intermediates }\end{array}$ & & $\mathrm{X}$ \\
\hline & $\begin{array}{l}\text { the cost of lost benefits in relation to the accepted demand and } \\
\text { supply options for the products or goods sold }\end{array}$ & & $\mathrm{X}$ \\
\hline
\end{tabular}

Source: Own calculations based on the results of pilot studies and P. Szczypa, Rola strategicznej rachunkowości zarządczej w zarządzaniu procesami logistycznymi [w:] Wykorzystanie narzędzi..., p. 65 .

The role of strategic management accounting in the control function (Table 4) is expressed by the provision of financial and non-financial information to measure and assess the achievement of key long-term objectives in the different logistical processes. On the basis of the information obtained, conclusions may be drawn concerning the implementation of logistic processes in the long term. The results of the pilot studies show that management accounting is not used to provide information on the management of logistics processes as an accounting control function. 


\section{CONCLUSION}

Strategic management accounting for the management of logistics processes is forwardlooking, even concerning relatively distant future. As A. Szewczuk writes: "The future is not a ready-made state of affairs, it is a realized, structured state of affairs just like the existing reality, but it is only one of the possible realization of the potential possibilities inherent in the present reality. The future must naturally be predicted. Define more or less precisely the shapes of what may come" 10 . Nowadays, managers expect strategic management accounting to provide both financial and non-financial information to determine the shape of future logistics processes and beyond. Therefore, the essential and most general accounting function should be considered to be the information function. Therefore, the role of strategic management accounting in the management of logistics processes is primarily to provide information about them. This information of a valuable and qualitative nature is to enable the performance of the function of management of separate logistics processes in a company.

The results of the pilot studies show that strategic management accounting is used very little as a source of information to support the management of logistics processes. The considerations made in the article show that strategic management accounting is highly capable of managing logistic processes with little application in practice. The studies carried out over the period 2010-2013 and the pilot studies in 2018 lead to the conclusion that the studies initiated should be continued and carried out on a representative sample in order to identify:

- tools of strategic management accounting used in enterprises;

- dysfunctional phenomena on the line of strategic management accounting management of logistics processes;

- phenomena desirable on the line of strategic management accounting - management of logistic processes;

- directions of using information possible to obtain from strategic management accounting in order to support management of logistic processes;

- strategic management accounting tools, which will be key to the management of logistics processes.

\section{REFERENCES}

1. Buko J., Wolska G., Zarzadzanie procesami logistycznymi w przedsiębiorstwach ustugowych [w:] Przedsiębiorstwo ustugowe. Zarzadzanie, red. B. Filipiak, A. Panasiuk, Wydawnictwo Naukowe PWN, Warszawa 2008.

2. Dembińska-Cyran I., Zarządzanie procesami logistycznymi w przedsiębiorstwach ustugowych [w:] Przedsiębiorstwo ustugowe. Zarzqdzanie, red. B. Filipiak, A. Panasiuk, Wydawnictwo Naukowe PWN, Warszawa 2008.

3. Filipiak-Dylewska B., Szewczuk A., Zarządzanie strategiczne. Narzędzia, scenariusze, procesy, Fundacja na rzecz Uniwersytetu Szczecińskiego, Szczecin 2000.

\footnotetext{
${ }_{10}$ B. Filipiak-Dylewska, A. Szewczuk, Zarzqdzanie strategiczne. Narzędzia, scenariusze, procesy,
} Szczecin 2000, p. 68. 
4. Halachmi A., Performance Measurement is Only one Way of Managing performance, "International Journal of Productivity and Performance Management" 2005, Vol. 54, issue 7.

5. Lew G., Rachunek kosztów klienta w zarządzaniu przedsiębiorstwem handlowym, Oficyna Wydawnicza Politechniki Rzeszowskiej, Rzeszów 2015.

6. Sobków Cz., Podstawy zarządzania, Wyższa Szkoła Humanistyczno-Ekonomiczna we Włocławku, Włocławek 2003.

7. Szczypa P., Rola strategicznej rachunkowości zarzadczej $w$ zarządzaniu procesami logistycznymi [w:] Wykorzystanie narzędzi rachunkowości w logistyce. Doświadczenia przedsiębiorstw polskich, niemieckich i białoruskich, red. B. Filipiak, Difin, Warszawa 2013.

8. Tokarska D., Narzędzia rachunkowości zarządczej jako wsparcie systemów motywacyjnych [w:] Studia Ekonomiczne Zeszyty Naukowe UE w Katowicach 300, Wydawnictwo UE w Katowicach, Katowice 2016.

\title{
STRATEGICZNA RACHUNKOWOŚĆ ZARZĄDCZA W ZARZĄDZANIU PROCESAMI LOGISTYCZNYMI. WYNIKI BADAŃ PILOTAŻOWYCH
}

\begin{abstract}
Zarządzanie procesowe w przedsiębiorstwach, w tym zarządzanie procesami logistycznymi jest przedmiotem zainteresowania zarówno nauki, jak i praktyki gospodarczej. Wymaga wsparcia informacyjnego, zapewniającego informacje ilościowe, wartościowe oraz jakościowe. Takim podsystemem informacyjnym w przedsiębiorstwie może być rachunkowość zarządcza. W publikacji rozważania zostały zawężone do strategicznej rachunkowości zarządczej. Celem opracowania jest: (1) zidentyfikowanie roli strategicznej rachunkowości zarządczej w zarządzaniu procesami logistycznymi; (2) wstępne określenie potrzeby i kierunku pogłębionych badań naukowych w zakresie strategicznej rachunkowości zarządczej w realizacji procesów logistycznych. Przyjęto następującą hipotezę: strategiczna rachunkowość zarzadcza generuje szeroki zakres informacji dotyczacych procesów logistycznych, jednak w praktyce możliwości te nie sq wykorzystywane przez menedżerów i wtaścicieli przedsiębiorstw. W ramach przeprowadzonych badań $\mathrm{z}$ wykorzystaniem analizy literatury, wyników projektu badawczego NN 113005839 zrealizowanego w latach 2010-2013, doświadczeń własnych autora oraz badań pilotażowych (wywiady bezpośrednie) w 10 przedsiębiorstwach zweryfikowano pozytywnie hipotezę.
\end{abstract}

Słowa kluczowe: rachunkowość, strategiczna rachunkowość zarządcza, procesy logistyczne.

DOI: $10.7862 /$ rz.2018.hss.88

Tekst złożono do redakcji: czerwiec $2018 \mathrm{r}$.

Tekst przyjęto do druku: grudzień 2018 r. 